\title{
Terapi Tafakkur untuk Meningkatkan Kesejahteraan Psikologis Orang dengan Lupus (Odapus)
}

\author{
Tarsono, Nisa Hermawati \\ UIN Sunan Gunung Djati, Jl. A. H. Nasution No. 105, Cibiru, Bandung \\ e-mail: tarsono@uinsgd.ac.id
}

\begin{abstract}
The purpose of this research was to evaluate the effect of tafakkur therapy on psychological well-being on people with odapus. This study used experimental method with a single case design using the variation of type A-B. The participant was a 24-year-old woman with sjorgen odapus from Syamsi Dhuha Foundation. The results showed that there were changes in psychological well-being between before and after attending tafakkur therapy. It touched the aspect of cognition, affection and psychomotor of the subject. The conclusion of the research was tafakkur therapy could affect psychological well-being on individual with odapus. There were also others factors that influence psychological well-being: social support, social economic status, social networks, religiosity, personality, and intensity of attending therapy activities.
\end{abstract}

Keywords: Tafakkur therapy, psychological wellbeing, Odapus

\begin{abstract}
Abstrak
Tujuan penelitian ini yakni untuk mengetahui seberapa besar pengaruh terapi tafakkur terhadap kesejahteraan psikologis odapus. Metode penelitian menggunakan desain eksperimental kasus tunggal (single-case experimental design) dengan tipe variasi A-B, disebabkan peneliti hanya ingin melihat seberapa besar peningkatan kesejahteraan psikologis pada odapus. Subjek merupakan seorang wanita berusia 24 tahun yang menderita lupus jenis sjorgen sebagai anggota Syamsi Dhuha Foundation. Alat ukur terdiri dari skala kesejahteraan psikologis dari Ryffs, pedoman wawancara serta kuesioner bagi significant others. Berdasarkan hasil pengukuran yang dilakukan kepada odapus, terdapat peningkatan kondisi kesejahteraan psikologis antara sebelum dan sesudah mengikuti terapi tafakkur. Terapi tafakkur menyentuh aspek kognisi, afeksi dan psikomotor subjek. Dapat disimpulkan bahwa terapi tafakkur berpengaruh terhadap kesejahteraan psikologis odapus. Selain itu terdapat faktor lain yang berpengaruh antara lain dukungan sosial, status ekonomi sosial, jaringan sosial, religiusitas, kepribadian, dan intensitas mengikuti kegiatan terapi.
\end{abstract}

Kata Kunci: Terapi Tafakkur, kesejahteraan psikologis, Odapus

\section{Pendahuluan}

Harapan setiap manusia di dunia ini adalah dapat hidup sehat dan sejahtera baik secara fisik ataupun psikologis hingga akhir hayatnya (Oliver, Tomás, \& MontoroRodriguez, 2017). Namun harapan tersebut tentunya tidak akan mungkin terjadi, karena manusia senantiasa akan dihadapkan pada situasi yang memiliki dua sisi yakni menyenangkan dan tidak menyenangkan (Oliver dkk., 2017). Situasi yang tidak menyenangkan, salah satunya adalah saat diberikan ujian rasa sakit. Saat seseorang mengalami sakit, tentunya akan berdampak pula pada kondisi psikologisnya. Sesuai dengan apa yang dikatakan oleh Sigmund Freud, bahwa terdapat keterkaitan antara pikiran dan tubuh (Armstrong, Lilford, Ogden, dan Wessely, 2007). Dimana dalam bukunya Goodwin dan Ogden, (2007), Freud menganalisis hubungan antara pikiran dan sakit fisik, Freud menggambarkan suatu kondisi yang dinamakan "hysterical paralysis" kondisi tersebut mengindikasikan jika ada kondisi dimana seseorang merepresi pengalaman dan perasaan yang terekspresikan dalam masalah fisik. Menurut kajian Psikologi Kesehatan, yang pendekatannya bersifat menyeluruh, yakni biopsikososial, mengatakan jika sakitnya seseorang itu dapat disebabkan 
karena beberapa faktor, bukan hanya faktor biologi saja seperti virus, bakteri atau makanan (Griffiths, Brennan, O'Gorman, Goedel, Sheffield, Bastian, dan Barlow, 2018). Tetapi lebih dari itu, antara lain dapat disebabkan karena faktor psikologis, seperti tingkah laku, belief, coping, stress, pain, dan faktor sosial seperti status sosial, pekerjaan, budaya, nilai, aturan (Griffiths dkk., 2018).

Setiap tingkah laku yang dilakukan oleh seseorang tentunya akan didahului oleh proses berfikir, karena bagaimanapun dalam hidupnya, manusia tidak akan mungkin terlepas dari aktivitas berpikir, baik disadari maupun tidak. Berdasarkan hal tersebut, sakitnya seseorang, dapat terasa menjadi lebih baik dengan adanya proses berpikir yang baik pula (Walker, 2018). Proses berpikirnya seseorang itu, dapat dilakukan dengan cara bermeditasi atau mendekatkan diri dengan sang pencipta (Ramdani, Supriyatin, \& Susanti, 2018). Tentunya bagi setiap orang Muslim menjadi suatu ketenangan pada saat lebih dekat dengan Allah Swt. Karena melalui proses berfikir yang mendalam sekaligus memahami apa yang sudah digariskan-Nya menjadi hal yang positif bagi seseorang untuk lebih memahami makna dari kehidupan itu sendiri, terutama bagi seseorang yang mengalami sakit (Ramdani dkk., 2018).

Hal tersebut di atas, jika disanding-kan dengan istilah yakni berbicara tentang masalah tafakkur. Tafakkur dalam istilah adalah merenungkan dan berpikir tentang apa yang Allah ciptakan (Badi, 2007). Bertafakkur ialah berbuat melalui pikiran atau berfikir dengan cara merenung atau merenungi ciptaan Allah (Badi, 2007). Badi (2007) mengatakan bahwa pangkal segala kebaikan dari perbuatan otak adalah tafakkur, sedangkan motivasinya adalah dari hati. Melalui tafakkur manusia senantiasa mengenal diri dan mengenal Tuhannya yaitu Allah Swt. dan segala keagunganNya.
Bagi seorang muslim, berpikir secara baik dan mendalam adalah awal dari terbukanya jalan menuju pengenalan dan pemahaman kepada Allah Swt., karena saat seseorang dapat berpikir positif terhadap sang Khaliknya, maka makna atau hakikat sebenarnya penciptaan hamba-Nya ke dunia ini akan jelas dimaknakan dan akan membuat seseorang menjadi lebih sehat dan terarah saat bertingkah laku maupun merasa (Abdel-Khalek, 2013). Seperti halnya ber-tafakkur, terkadang seseorang belum mengetahui apa itu tafakkur, untuk apa ber-tafakkur serta dapat dilakukan seperti apakah tafakkur itu dan lebih jauh lagi jika dikaji dan dihubungkan dengan kajian Psikologi, apa keterkaitannya atau pengaruhnya saat seseorang ber-tafakkur kepada Allah Swt. (Badi, 2007).

Kata 'tafakkur' disebut dalam Al-quran sejumlah 18 pengulangan yang ter-dapat dari dua bentuk turunnya Alquran (makiyah dan madaniyah). Tujuan dari tafakkur ini adalah menyempurnakan diri agar mendapatkan akhlak yang mulia dan senantiasa meninggikan derajat keimanan.

Seperti halnya, di salah satu yayasan yang di dalamnya terdapat para penyandang lupus, yakni di Syamsi Dhuha Foundation, terdapat terapi yang dilakukan bagi para orang dengan lupus ini, dinamakan sebagai terapi tafakkur, program ini sudah berlangsung lama dan menjadi hal yang rutin dilakukan setiap minggunya bagi para penyandang lupus. Adapun yang dilakukan dalam terapi tafakkur ini antara lain, mengkaji Alquran dan melakukan sesi sharing bersama ahli juga bersama para penyandang lupus yang berhasil survive.

Lupus ialah semacam penyakit yang didiagnosa berhubungan dengan anti-body manusia, penyakit lupus memiliki banyak kesamaan gejala dengan penyakit lain pada umumnya, oleh karenanya diagnosis penyakit ini sangatlah beragam (Kwon, Lee, Ghang, Kim, Lee, Yoo, \& Hong, 2018). Penyakit ini diprediksi sudah banyak dibuktikan bisa dianggap sebagai penyakit biasa dan bisa juga sampai tingkat yang 
mematikan (Kwon dkk., 2018). Tidak ada penularan gejala atau jenis sakitnya dalam lupus ini.

Infeksi atau perubahan pada kulit, rasa capek, nyeri dan bengkak sendi merupakan gejala umum pada penyakit lupus. Penyakit ini juga dikategorikan sebagai autoimun, artinya, ada penyerangan antara sistem imun seseorang yang berdampak pada tubuh seseorang tersebut. Sejauh ini, penyebabnya belum dapat diketahui, namun akibatnya terhadap bagian-bagian vital tubuh sudah banyak dibuktikan (Kiriakidou, 2013).

Sebagian orang menganggap bahwa hal yang menyebabkan terjadinya sakit lupus ini adalah adanya faktor lingkungan dan keturunan. Terdapat kurang lebih lima juta manusia di dunia mengidap penyakit lupus. Dari lima juta tersebut wanita menduduki dominasi terbanyak terutama pada masa produktif antara umur $15-50$ tahun. Namun, terdapat kemungkinan juga penyakit lupus mengancam anak-anak dan laki-laki. Berdasarkan data yang dirilis oleh Yayasan Lupus Indonesia terhitung pada tahun 2012, berjumlah total sebanyak 12,700 jiwa. Kemudian jumlah ini meningkat pada tahun 2013 sebanyak 600 jiwa sehingga jumlahnya menjadi 13,300 jiwa (Republika.co.id, 2013 ).

Berkaitan dengan masalah psikologis, orang yang mengidap penyakit ini haruslah senantiasa baik dalam menjaga kesetabilan psikologisnya. Tingkat diagnosis diharapkan tidak menjadi akut dengan stres yang dianggap timbul dari ketidakstabilan psikologis (Armstrong dkk., 2007). Artinya, kesejahteraan psikologis orang dengan lupus (odapus) harus tetap konsisten baik dan terjaga.

Kesejahteraan psikologis menurut pendapat Ryff merupakan adanya karakteristik seseorang yang menunjukkan perkembangan diri dengan menghargai diri secara positif dalam bentuk kesadaran terhadap kemampuan diri, hal ini biasa disebut dengan istilah self-acceptance, memiliki relasi yang baik dengan orang lain (positive relation with others), adanya kemampuan dalam membentuk keadaan dan kondisi lingkungan (environmental mastery), memiliki kepercayaan terhadap diri sendiri dan kebebasan individu (autonomy), selalu belajar dan mengembangkan diri (personal growth), terdapat tujuan hidup sehingga senantiasa selalu berusaha dan selalu menyelesaikan masalah (Ryff dan Singer, 2008).

Selanjutnya, kesejahteraan psikologis dipengaruhi oleh faktor kepribadian, emosi, kesehatan, relasi, dan kelas sosial (Ryan \& Deci, 2001; Deci \& Ryan, 2008). Selain itu, usia dan jenis kelamin juga termasuk hal yang memiliki pengaruh terhadap kesejahteraan psikologis sese-orang (Ryff, 1989).

Karakteristik kesejahteraan psikologis seseorang dapat dilihat dari bentuk tingkat depresi, rasa bahagia, dan kepuasan terhadap apa yang ia miliki dalam hidupnya (Joshanloo, 2018). Lalu digambarkan Rogers adalah orang yang memiliki fungsi penuh (fully functioning person), sementara Maslow menyatakan seseorang yang memiliki aktualisasi diri (self actualization), kemudian individualisasi digambarkan oleh Jung dan konsep mengenai kematangan digambarkan Allport. Lebih luas Erikson menggambarkan individu yang tidak putus asa dan memiliki integrasi (Ryff, 1989).

Kesimpulannya, bahagia, puas terhadap hidup, tidak depresi merupakan bentuk dari kesejahteraan psikologis seseorang. Hal demikian dikatakan pula oleh Bradburn (dalam Ryff dan Singer, 2008), kesejahteraan psikologis pada hakikatnya ialah keadaan yang sangat bernilai dan selalu menjadi dambaan setiap orang untuk mendapatkannya.

Seterusnya, organisasi kesehatan dunia (WHO) menggagas manusia yang memiliki karakteristik tidak sakit selain daripada mentalnya yaitu adanya aspek agama sehingga tidak hanya sehat secara fisik atau jasmani bahkan sosial akan tetapi sehat berdasarkan spiritual (bio-psiko-sosio- 
spiritual). Sedangkan yang bisa menjamin sehat seseorang secara hakikatnya tidak hanya dokter akan tetapi adanya keterlibatan kehendak Tuhan dalam prosesnya, sebagaimana disabdakan oleh Rasulullah Muhammad Saw. "setiap penyakit ada obatnya, jika obat itu tepat sasaran, maka dengan izin Allah penyakit itu akan sembuh".

Terdapat banyak penelitian berkaitan dengan fenomena odapus, diantaranya yaitu tingkat depresi antara rentang 8\% - 44\% karena adanya keterbatasan beraktivitas dari seseorang akibat sakit pada sendi yang disebabkan penyakit lupus (McElhone, Abbott, Gray, Williams, \& Teh, 2010).

Adapun beberapa penelitian sebelumnya mengenai Tafakkur, antara lain tafakur seringkali dikaitkan dengan kegiatan kognitif dalam Psikologi yaitu adanay kegiatan afektif disamping aktivitas berfikir (Purwanto, 2007). Menurut Al-Ghazali (dalam Badi, 2007) perbuatan seseorang berubah yang disebabkan oleh keinginan hati yang berilmu. Dalam hal ini kegiatan berkaitan dengan keadaan atau mengikuti keadaan, juga mengikuti ilmu dan ilmu berasal dari fikiran, itu sebabnya pikiran merupakan kunci kebaikan melalui cara tafakkur. Adapun penelitian Mawarni, Indriyana, dan Masykur (2006) memberikan gambaran mengenai kondisi psikologis anggota salah satu thariqoh yaitu Qadariyah Naqsyabandiyah dalam melaksanakan tafakkur, diantaranya ialah: menemukan hikmah dalam kehidupan dengan menghayati segala yang terjadi di dunia, mempertebal tingkat keimanan pada Allah, merenung secara reflektif maupun kontemplatif tentang segala hal. Pola tafakkur ini memperlihatkan adanya kerja hati, pikiran dan rohani yang dapat menjadikan orang lebih religius. Adapun hasil penelitian yang lebih spesifik pada penyandang lupus di Syamsi Dhuha Foundation, diketahui bahwa kesejahteraan psikologis mereka tergambar dari adanya makna dan tujuan hidup yang jelas, tetapi masih terdapat permasalahan berkenaan dengan lingkungan sekitar yang menyebabkan sulitnya hubungan secara terbuka dan hangat (Citra \& Eriany, 2015).

Penelitian ini termasuk hal yang baru diteliti, adapun sesuatu yang unik pada penelitian ini adalah terletak pada penggunaan intervensi yang sifatnya religius terhadap para odapus yakni melalui terapi tafakkur, karena sebelumnya pendekatan yang dilakukan hanya melalui intervensi yang sifatnya biomedis atau melalui obatobatan, dan olah raga seperti senam sehat, namun di Yayasan Syamsi Dhuha ini salah satu bentuk intervensinya adalah melalui terapi tafakkur yang dilakukan rutin setiap minggu sehingga peneliti tertarik untuk mengevaluasi sejauhmana pengaruhnya terhadap kesejahteraan psikologis para odapus.

Berdasarkan fenomena tersebut, yayasan Syamsi Dhuha Foundation melakukan pendekatan melalui terapi tafakkur terhadap para odapus yang tergabung di yayasan dan dilakukan secara rutin yakni seminggu sekali. Peneliti merasa sangat tertarik untuk meneliti lebih lanjut, apakah terdapat pengaruh program terapi tafakkur yang dilakukan oleh yayasan terhadap kesejahteraan psikologis para odapus. Dengan demikian penelitian ini bertujuan untuk mengetahui gambaran kesejahteraan psikologis odapus pada sebelum maupun setelah dilakukannya terapi tafakkur serta bagaimana pengaruh dari terapi tafakkur tersebut bagi kesejahteraan psikologis mereka.

\section{Metode Penelitian}

Pada penelitian ini, peneliti menggunakan mixed method research, dimana peneliti sangat ingin melihat outcomes dan prosesnya. Jenis penelitian ini dirancang untuk mengikuti prosedur yang semestinya, di mana di dalamnya ada campuran metode antara kualitatif dan kuantitatif. Dengan dicampurkannya dua metode ini, diharapkan bahwa sebuah penelitian akan menjadi lebih baik dan membantu peneliti untuk 
leih memahami permasalahan yang sedang dibahas (Cresswell \& Clark, 2011).

Pendekatan mixed method yang dimaksud terdiri dari pendekatan kuantitatif berupa rancangan single-case experimental design, dengan tipe A-B. Selain itu peneliti juga menggunakan pendekatan kualitatif melalui teknik wawancara serta observasi. Skema rancangan disajikan pada gambar 1 .

\section{O_O_O_X_O_X O X O X O}

Fase A PostTest Fase B

Gambar 1. Skema Single-Case Experimental Design Tipe A-B (Sunanto, 2005)

Subjek dalam penelitian ini adalah partisipan tunggal yaitu seorang wanita berusia 24 tahun, berstatus sebagai mahasiswa, yang menderita penyakit lupus jenis sjorgen dan merupakan anggota pada Syamsi Dhuha Foundation. Dalam penelitian ini dilibatkan pula seorang significant other yaitu mentor yang menjadi pendamping subjek pada setiap sesi terapi.

Terapi tafakkur sebagai independent variable dalam penelitian ini, diartikan sebagai kegiatan rutin setiap minggu yang diselenggarakan di Yayasan Syamsi Dhuha, yang ditujukan sebagai kegiatan teurapetik bagi para anggota, sebagai individu yang mengalami penyakit lupus. Sasaran kegiatan ini adalah sejauhmana menggugah aspek kognitif, afektif serta psikomotor meliputi tahapan kegiatan yang dimulai dengan membaca Alquran, menegaskan tujuan tafakkur, penyampaian materi tafakkur secara interaktif, serta kesimpulan berupa sharing dan evaluasi.

Dalam penelitian ini digunakan beberapa teknik yaitu wawancara, observasi, skala kesejahteraan psikologis dari Ryff, serta kuesioner. Skala kesejahteraan psikologis merupakan alat ukur yang dibuat oleh Ryff terdiri dari 42 item yang mengukur enam dimensi yaitu selfacceptance, positive relation with others, environmental mastery, autonomy, personel growth, serta tujuan hidup. Alat ukur ini memiliki validitas dan reliabilitas yang baik, validitas antara .86-.93 serta reliabilitas antara .81-.88. Skala ini diberikan secara berkala kepada subjek baik pada 3 sesi fase baseline maupun setiapkali selesai mengikuti 4 sesi terapi tafakkur. Selain pengukuran melalui skala tersebut, dilakukan wawancara terhadap subjek menggunakan pedoman yang disusun dengan mengacu kepada dimensidimensi yang dikemukakan oleh Ryff tersebut. Adapun kuesioner berupa pertanyaan terbuka untuk menilai dimensidimensi kesejahteraan psikologis, yang diisi oleh mentor (significant other) pada setiap sesi sebagai data penunjang guna memperkuat hasil pengukuran melalui skala, wawancara serta observasi terhadap subjek penelitian.

Prosedur utama yang ditempuh dalam desain A-B meliputi pengukuran target behavior pada fase baseline dan setelah trend serta level datanya stabil kemudian intervensi mulai diberikan. Selama fase intervensi target behavior secara kontinyu dilakukan pengukuran sampai mencapai data yang stabil (Lovaas: 2003, Tawney \& Gast, 1984). Jika terjadi perubahan target behavior pada fase intervensi setelah dibandingkan dengan baseline, diasumsikan bahwa perubahan tersebut karena adanya pengaruh dari variabel independen atau intervensi.

Langkah-langkah yang dilakukan dalam penelitian ini meliputi dua fase, yaitu: pertama, fase A (Baseline). Pada fase baseline ini peneliti hanya melakukan pengukuran terhadap kondisi kesejahteraan psikologis subjek sebelum mengikuti kegiatan terapi tafakkur. Pengukuran dilakukan selama 3 minggu. Kedua, fase B (pemberian perlakuan/ intervensi). Pada fase ini perilaku yang menjadi target diukur selama klien diberikan penanganan yaitu kesejahteraan psikologis subjek, yang dilihat dari beberapa aspeknya. Fase penanganan diberikan selama 4 minggu setelah fase baseline. Dalam fase perlakuan ini odapus mengikuti terapi tafakkur. Pada saat 
itulah peneliti melakukan observasi kepada subjek, yakni selama 4 minggu, dan melakukan pengukuran dengan menggunakan skala kesejahteraan psikologis serta dilengkapi wawancara.

Teknik analisis data menggunakan statistik deskriptif berupa penyajian data hasil penelitian dalam bentuk grafik. Analisis ini dipilih sesuai dengan rancangan penelitian, dimana subjek penelitian hanya terdiri dari satu partisipan. Penarikan kesimpulan mengenai hipotesis penelitian dilihat berdasarkan ada tidaknya kenaikan grafik dari kondisi baseline menuju treatment.

\section{Hasil Penelitian dan Pembahasan}

\section{Hasil Penelitian}

Berdasarkan perolehan skor kesejahteraan psikologis dari setiap sesi, maka data tersebut dapat disajikan ke dalam sebuah kategori tertentu sesuai dengan rentang yang telah disusun. Kategori diperoleh melalui rentang skala $(\mathrm{RS})=\mathrm{n}(\mathrm{m}-1) / \mathrm{m}$. Skor terrendah alat ukur adalah 42 sedangkan skor tertinggi adalah 294. Banyaknya alternatif adalah 7 , sehingga diperoleh RS = 42(7-1)/7 = 252/7 = 36 . Maka untuk membuat rentang skalanya, karena 42 adalah nilai terendah, maka 42 ditambah RS hasilnya $42+36=78$. Demikian seterusnya ditambah 36 sampai skor tertinggi 294. Hasil penyusunan kategori secara lengkap disajikan pada tabel 1 .

Berdasarkan pengolahan data diperoleh hasil gambaran skor total maupun setiap aspek serta kategori dari kesejahteraan psikologis subjek pada setiap sesi sebagaimana tersaji pada tabel 2. Selain itu juga table 2 dibawah ini disajikan terkait skor kesejahteraan untuk setiap aspeknya. Pada tabel 2 dapat dilihat bahwa sebaran skor pada setiap aspek kesejahteraan psikologis, yang mana skor total pada fase baseline menunjukkan bahwa keadaaan subjek masih berada pada kategori rendah sekali dan mulai berangsur menjadi baik sampai dengan sangat baik terutama pada fase treatment.

Tabel 1

Rentang Skala Skor Kesejahteraan Psikologis

\begin{tabular}{lc}
\hline \multicolumn{1}{c}{ Nilai Rentang Skala } & Kategori \\
\hline $42-78$ & Rendah Sekali (RS) \\
$79-114$ & Rendah (R) \\
$115-150$ & Cukup (C) \\
$151-186$ & Cukup Baik (CB) \\
$187-222$ & Baik (B) \\
$223-258$ & Baik Sekali (BS) \\
$258-294$ & Sangat Baik (SB) \\
\hline
\end{tabular}

Tabel 2

Sebaran Skor Kesejahteraan Psikologis per Aspek

\begin{tabular}{lccccccc}
\hline & \multicolumn{3}{c}{ Baseline } & \multicolumn{4}{c}{ Treatment } \\
\cline { 2 - 8 } Aspek & $(1)$ & $(2)$ & $(3)$ & $(1)$ & $(2)$ & $(3)$ & $(4)$ \\
\hline 1 & 9 & 9 & 18 & 27 & 36 & 45 & 45 \\
2 & 6 & 6 & 18 & 27 & 36 & 45 & 45 \\
3 & 6 & 6 & 18 & 27 & 36 & 45 & 46 \\
4 & 10 & 10 & 20 & 30 & 40 & 50 & 50 \\
5 & 4 & 4 & 8 & 16 & 24 & 28 & 28 \\
6 & 7 & 7 & 14 & 21 & 28 & 35 & 49 \\
Total & 42 & 42 & 96 & 148 & 200 & 248 & 263 \\
Kate- & $\mathrm{RS}$ & $\mathrm{RS}$ & $\mathrm{R}$ & $\mathrm{C}$ & $\mathrm{B}$ & $\mathrm{BS}$ & $\mathrm{SB}$ \\
gori & & & & & & & \\
\hline
\end{tabular}

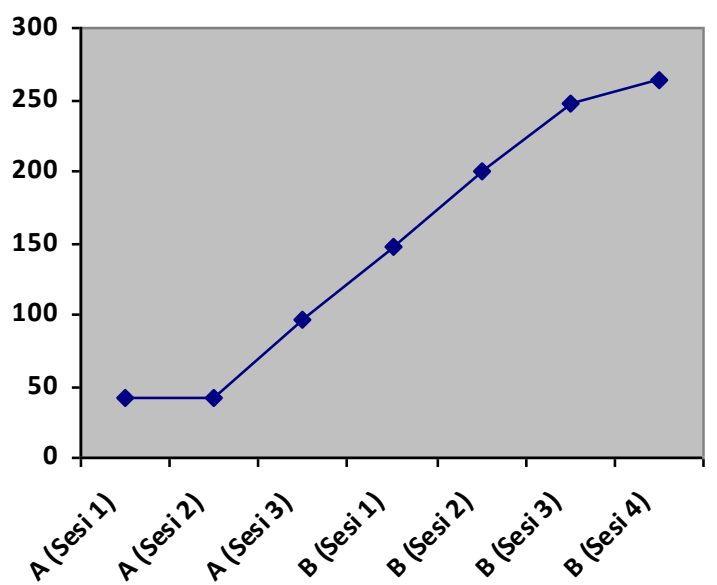

Gambar 1. Grafik skor skala kesejahteraan psikologis

Berdasarkan gambar 1, kondisi kesejahteraan psikologis subjek ketika dibandingkan antara fase baseline dengan fase treatment, atau fase sebelum mengikuti terapi tafakkur dengan setelah mengikuti terapi tafakkur menunjukkan adanya perbedaan. Pada fase baseline, kondisi 
kesejahteraan psikologis cenderung masih berada di rentang skor 'rendah sekali' sampai dengan 'rendah', sedangkan saat mulai mengikuti terapi tafakkur atau pada fase treatment, kondisi kesejahteraan psikologisnya berangsur-angsur meningkat skornya dari mulai 'cukup' sampai dengan 'baik sekali'. Dengan demikian dapat diartikan bahwa terapi tafakkur yang diberikan kepada subjek, dapat meningkatkan kesejahteraan psikologisnya.

Perubahan yang dialami subjek, diperkuat oleh mentor atau pendamping saat proses terapi, yang mana subjek mengalami perubahan yang sangat signifikan, antara sebelum dan sesudah melakukan terapi tafakkur. Berdasarkan pengamatan mentor, subjek pada awalnya selalu mengeluh dan sulit untuk menerima diri dengan diagnosa yang dialami sehingga sangat berpengaruh pada aktivitas akademik juga sosialnya. Namun setelah mulai bergabung dan ikut dalam terapi tafakkur, subjek berangsur mulai mampu membuka diri terhadap lingkungan sosial dan mulai kembali membuat rencanarencana dalam hidupnya. Selain itu juga terlihat bersemangat dan tidak mudah menyerah.

\section{Pembahasan}

Kondisi kesejahteraan psikologis subjek (orang dengan lupus) antara sebelum mengikuti terapi tafakkur dengan setelah mengikuti terapi tafakkur mengalami perubahan. Subjek awalnya mengalami kesulitan untuk menerima dengan kondisi dirinya yang didiagnosa lupus, sehingga berpengaruh pada aspek yang lainnya seperti kemampuannya dalam melakukan hubungan dengan orang lain, kemampuan untuk dapat mengembangkan diri, kemampuannya dalam mengontrol lingkungan, kemandirian dan juga tujuan hidupnya. Hal tersebut sangat menggambarkan bagaimana kondisi seseorang saat pertama kali didiagnosa sakit parah, karena saat seseorang didiagnosa sakit lupus artinya harus siap dengan konsekuensi yang akan dialami.

Jika melihat sakit yang dialami oleh subjek, memang akan terasa berat untuk menjalaninya dan membutuhkan kesiapan untuk menerima dirinya didiagnosa sakit parah. Lupus merupakan penyakit seribu wajah yang dapat menyerang bagian tubuh dan menyebabkan yang mengalaminya menjadi lemah secara fisik. Selain itu, dapat memengaruhi juga kondisi psikologis penderitanya, seperti kurang motivasi dan seringnya berubah mood. Seperti halnya Lestari dan Masykur (2014) mengemukakan bahwa penyakit lupus merupakan penyakit yang tidak hanya menimbulkan sakit pada fisik, tapi seringkali penderita mengalami gangguan mental karena penyakit ini nampak pada permukaan kulit pada umumnya sehingga banyak orang yang menderita penyakit ini memiliki mental yang tidak baik.

Penyakit lupus yang menyebabkan timbulnya sakit mental pada penderita hendaknya harus segera diantisipasi dengan adanya bimbingan atau konseling. Karena kesehatan mental belum tentu bisa disembuhkan dengan proses medis maka dari itu hadirnya psikologi, bimbingan, konseling, dan terapi merupakan solusi bagi para penderita yang memiliki kendala pada mental mereka yang disebabkan oleh penyakit lupus yang diderita (Lestari \& Masykur, 2014).

Berdasarkan apa yang dialami oleh subjek, dapat disimpulkan jika dampak dari sakit lupus tidak hanya berpengaruh pada kondisi fisik melainkan berpengaruh juga pada kondisi psikologisnya. Seperti yang dilakukan oleh subjek, dalam melakukan pengobatan subjek senantiasa tidak pernah terlepas dari obat, sedangkan untuk aspek psikologisnya, subjek mencoba bergabung di Yayasan Syamsi Dhuha, dimana yayasan tersebut terdapat beberapa program yang tidak saja hanya melayani seputar obat lupus, namun terdapat pengobatan yang sifatnya menyentuh psikologis para odapus, antara lain terdapat senam lupus 
dan taffakuran (terapi tafakkur), tafakkur merupakan salah satu program yang rutin dilakukan di Yayasan Syamsi Dhuha, dan dijadikan sebagai kegiatan bersama para odapus dengan tujuan agar para odapus dapat menyelami dirinya dengan cara bertafakkur. Hal ini termasuk ke dalam pengobatan yang berbasis pada pendekatan dan nilai keislaman (Edriss, Rosales, Nugent, Conrad, \& Nugent, 2017).

Terapi tafakkur yang dimaksudkan adalah pendekatan dengan merenungkan dan berpikir juga menggunakan akal untuk menelaah dan melihat keagungan Allah baik dari sifat-sifatnya atau dari segala apapun yang Allah ciptakan di dunia ini (Hamidi, Bagherzadeh, \& Gafarzadeh, 2010). Kegiatan tafakkur ini adalah salah satu aktivitas yang termasuk ke dalam terapi yang didasarkan pada konsepsi adanya kekuatan di luar personal mereka penderita yang mampu menguatkan kesehatan mereka sendiri (Yaacob, 2013). Menurut sendiri Yaacob (2013) aktivitas tafakkur ini mengacu kepada proses terapi kognitif yang mencoba mengkontruksi ulang pemahaman individu penderita lupus untuk mampu bertahan dan menjadikan kondisi yang mereka alami sebagai sesuatu yang mereka terima dengan lapang dada. Proses terapi tafakkur yang dilakukan dengan konsisten dan penuh penghayatan akan memberikan kepercayaan diri tinggi kepada penderita yang kemudian menjadi kebiasan positif untuk selalu kuat dalam menghadapi berbagai persoalan hidup (Kamarulzaman \& Saifuddeen, 2010).

Selain dalam Islam, tafakkur dikenal juga dengan istilah lain dalam Psikologi, yaitu tafakkur sebagai aktivitas kognitif. Kognitif berarti adanya proses yang mengandalkan otak sebagai media dalam melakukannya (Yaacob, 2013). Kognitif berarti representasi konsep-konsep mengenai segala hal baik itu diri sendiri, alam semesta dan bahkan tentang Tuhan. Al-Ghazali mengatakan proses kognitif selain menggunakan otak juga dimotivasi oleh kehendak hati sehingga tidak hanya aktivitas kognitif saja yang melakukan sesuatu akan tetapi akan ada implikasinya dalam kehidupan (Badi, 2007). Tafakkur juga bukan hanya tentang aspek kognitif. Ketika kita merenungkan (salah satu cara tafakkur), aspek emosional (dalam bentuk kesedihan, ketakutan, kemarahan dan ketundukan) juga muncul (Hamidi dkk., 2010). Juga aspek estetika (dalam mengagumi ciptaan Tuhan) yang melibatkan kasih sayang kita juga (Rosmarin, Alper, \& Pargament, 2015).

Berdasarkan analisis di atas, bahwa meningkatnya kesejahteraan psikologis subjek bukan saja disebabkan mengikuti terapi tafakkur, namun diperkuat juga oleh faktor lainnya yakni dukungan sosial, status ekonomi sosial, jaringan sosial, religiusitas dan kepribadian serta intensitas mengikuti kegiatan terapi (Hamidi dkk., 2010). Hal ini diperoleh dari hasil wawancara yang dilakukan terhadap subjek guna melihat faktor apa saja yang ikut berpengaruh pada kesejahteraan psikologisnya yang semakin membaik. Diperoleh data, subjek selama proses melakukan terapi senantiasa mendapatkan dukungan dari keluarga juga dari mentornya. Selain itu, meskipun subjek berasal dari keluarga yang cukup, subjek mendapatkan dukungan donator sehingga dalam proses penyembuhan menjadi lebih cepat. Dalam jaringan sosial pun subjek termasuk orang yang aktif menjalin relasi dengan teman-temannya meskipun sempat cuti kuliah, namun subjek dapat terus melakukan jaringan sosial. Subjek termasuk individu yang sangat religius dan bersungguh-sungguh dalam mendalami agama sehingga dalam proses terapi tafakkur ia mudah untuk menyerap dan mudah pula dalam melakukan proses muhasabah (instrospeksi diri). Selain itu secara pribadi pun, subjek termasuk individu yang extrovert, yang mana subjek bersikap asertif saat ada sesuatu yang ingin diungkapkan, sehingga permasalahan yang dialami mudah untuk disampaikan dan dicarikan solusinya. 


\section{Simpulan dan Saran}

\section{Simpulan}

Berdasarkan hasil dan pembahasan, dapat disimpulkan bahwa terapi tafakkur berpengaruh terhadap meningkatnya kesejahteraan psikologis subjek dengan lupus. Hal ini terlihat dari peningkatan setiap aspek kesejahteraan psikologis dalam setiap sesi terapi tafakkur. Dimana pada fase baseline kondisi kesejahteraan psikologis subjek terlihat rendah, setelah fase treatment yakni setelah mengikuti kegiatan terapi tafakkur, kondisi kesejahteraan psikologis subjek meningkat menjadi lebih baik.

Diperoleh juga gambaran mengenai faktor lain yang ikut berpengaruh pada meningkatnya kesejahteraan psikologis subjek, antara lain dukungan sosial, status sosial ekonomi, jaringan sosial, religiusitas dan kepribadian. Selain itu intensitas melakukan terapi juga harus diperhatikan karena berpengaruh terhadap perkembangan kesejahteraan psikologis odapus.

\section{Saran}

Beberapa saran yang dapat diberikan diantaranya: pertama, bagi para Odapus. Hasil penelitian dapat menjadi acuan bagi mereka bahwa terapi tafakkur berpengaruh terhadap meningkatnya kesejahteraan psikologis. Selain itu para odapus yang mengikuti terapi tafakkur, hendaknya secara rutin mengikuti kegiatan tersebut karena guna meningkatkan kesejahteraan psikologis. Kedua, bagi Yayasan Syamsi Dhuha. Mengingat pengaruh positif dari kegiatan terapi tafakkur, sehingga dapat terus dilaksanakan secara rutin, namun demikian terdapat faktor lain yang harus diperhatikan yaitu intensitas mengikuti kegiatan tersebut dari para odapus. Ketiga, bagi penelitian selanjutnya. Berkaitan dengan faktor lain yang turut berpengaruh terhadap meningkatnya kesejahteraan psikologis, antara lain dukungan sosial, status sosial ekonomi, jaringan sosial, religiusitas dan kepribadian. Maka disaran- kan untuk meneliti beberapa faktor tersebut secara kuantitatif pada beberapa odapus untuk dicari faktor manakah yang berpengaruh besar terhadap meningkatnya kesejahteraan psikologis. Selain itu, dalam penelitian ini subjek penelitian hanya satu orang odapus, sehingga ke depannya dapat juga diteliti lebih banyak subjek dengan karakter lupus yang berbeda sehingga dapat dibandingkan hasilnya secara lebih mendalam.

\section{Daftar Pustaka}

Abdel-Khalek, A. M. (2013). Personality dimensions and religiosity among Kuwaiti Muslim college students. Personality and Individual Differences, 54(2), 149-152. doi.org/10.1016/j.paid.2012.08.004

Armstrong, D., Lilford, R., Ogden, J., \& Wessely, S. (2007). Health-related quality of life and the transformation of symptoms. Sociology of Health and Illness, 29(4), 570-583. doi.org/10.1111/j.14679566.2007.01006.x

Badi, J. A. (2007). Tafakkur from a Qur' anic Perspective. Gezira Journal, 8(1).

Citra, L. R. A., \& Eriany, P. (2015). Penerimaan diri pada remaja puteri penderita Lupus. Psikodimensia, 14(1), 67-86. doi.org/10.24167/psiko.v14i1.374

Deci, E. L., \& Ryan, R. M. (2008). Hedonia, eudaimonia, and well-being: An introduction. Journal of Happiness Studies, $9(1), \quad 1-11$. doi.org/10.1007/s10902-006-9018-1

Edriss, H., Rosales, B. N., Nugent, C., Conrad, C., \& Nugent, K. (2017). Islamic medicine in the middle ages. American Journal of the Medical Sciences, 354(3), 223-229. doi.org/10.1016/j.amjms.2017.03.021

Goodwin, P., \& Ogden, J. (2007). Women's reflections upon their past abortions: An exploration of how and why emotional reactions change over 
time. Psychology and Health, 22(2), 231-248. doi.org/10.1080/14768320600682384

Griffiths, S., Brennan, L., O'Gorman, B., Goedel, W. C., Sheffield, J., Bastian, B., \& Barlow, F. K. (2018). Experiences of weightism among sexual minority men: Relationships with Body Mass Index, body dissatisfaction, and psychological quality of life. Social Science and Medicine, 214(August), 35-40. doi.org/10.1016/j.socscimed.2018.08.0 18

Hamidi, F., Bagherzadeh, Z., \& Gafarzadeh, S. (2010). The role of islamic education in mental health. Procedia - Social and Behavioral Sciences, 5, 1991-1996. doi.org/10.1016/j.sbspro.2010.07.402

Joshanloo, M. (2018). Longitudinal associations between subjective and psychological well-being in Japan: A four-year cross-lagged panel study. Personality and Individual Differences, 134(November 2017), 289-292. doi.org/10.1016/j.paid.2018.06.033

Kamarulzaman, A., \& Saifuddeen, S. M. (2010). Islam and harm reduction. International Journal of Drug Policy, 21(2), 115-118. doi.org/10.1016/j.drugpo.2009.11.003

Kiriakidou, M. (2013). Systemic Lupus Erythematosus. Annals of Internal Medicine (Vol. 159). Elsevier Inc. doi.org/10.7326/0003-4819-159-7201310010-01004

Kwon, O. C., Lee, J. S., Ghang, B., Kim, Y. G., Lee, C. K., Yoo, B., \& Hong, S. (2018). Predicting eventual development of lupus nephritis at the time of diagnosis of systemic lupus erythematosus. Seminars in Arthritis and Rheumatism. doi.org/10.1016/j.semarthrit.2018.02.0 12

Lestari, S., \& Masykur, A. (2014). Hardiness (ketabahan) pada wanita penderita lupus. Empati, 1-12.

Mawarni, N. I., Indriyana, Y., \& Masykur, A. M. (2006). Dinamika psikologis tafakur pada anggota Thariqoh Qodiriyyah Wa Naqsabandiyyah di Pondok Pesantren Futuhiyyah, Mranggen, Demak. Jurnal Psikologi Universitas Diponegoro, 3(2), 49-68.

McElhone, K., Abbott, J., Gray, J., Williams, A., \& Teh, L. S. (2010). Patient perspective of systemic lupus erythematosus in relation to healthrelated quality of life concepts: A qualitative study. Lupus, 19(14), 1640-1647. doi.org/10.1177/0961203310378668

Oliver, A., Tomás, J. M., \& MontoroRodriguez, J. (2017). Dispositional hope and life satisfaction among older adults attending lifelong learning programs. Archives of Gerontology and Geriatrics, 72, 80-85. doi.org/10.1016/j.archger.2017.05.008

Ramdani, Z., Supriyatin, T., \& Susanti, S. (2018). Perumusan dan pengujian instrumen alat ukur kesabaran sebagai bentuk coping strategy. Jurnal Psikologi Islam Dan Budaya, 1(2), 97-106.

Rosmarin, D. H., Alper, D. A., \& Pargament, K. I. (2015). Religion, spirituality, and mental health. Encyclopedia of Mental Health: Second Edition, 4, 23-27. doi.org/10.1016/B978-0-12-3970459.00190-7

Ryan, R. M., \& Deci, E. L. (2001). On Happiness and human potentials: A review of research on hedonic and eudaimonic well-being. Annual Review of Psychology, 52(1), 141166.

doi.org/10.1146/annurev.psych.52.1.1 41

Ryff, C. D. (1989). Beyond Ponce de Leon and life satisfaction: New directions in quest of successful ageing. International Journal of Behavioral Development, 12(1), 35-55. 
doi.org/10.1177/01650254890120010

2

Ryff, C. D., \& Singer, B. H. (2008). Know thyself and become what you are: A eudaimonic approach to psychological well-being. Journal of Happiness Studies, $9(1)$, 13-39. doi.org/10.1007/s10902-006-9019-0

Walker, S. (2018). Positive patient outcomes: More than a degree. Teaching and Learning in Nursing, 13(4),

A13-A15. doi.org/10.1016/j.teln.2018.06.001

Yaacob, N. R. N. (2013). Cognitive therapy approach from Islamic psychospiritual conception. Procedia - Social and Behavioral Sciences, 97, 182187.

doi.org/10.1016/j.sbspro.2013.10.220 
Psympathic, Jurnal Ilmiah Psikologi Desember 2018, Vol. 5, No. 2, Hal. : 175-186 